\title{
Antioxidant Effects of Ponciri Fructus Bioconversion Extracts as Cosmetic Ingredients
}

\author{
Gyu Bin Kong ${ }^{1}$, Oh Hyeok Kwon ${ }^{2 *}$ \\ ${ }^{1}$ Major of Beauty Design Magagement, Department of Media Design, Hansung University, Seoul, Korea \\ ${ }^{2}$ Department of Beauty Design Management, Hansung University, Seoul, Korea
}

\author{
*Corresponding author: Oh Hyeok Kwon, \\ Department of Beauty Design Management, \\ Hansung University, 116 Samseongyo-ro \\ 16-gil, Seongbuk-gu, Seoul 02876, Korea \\ Tel.: +82 27604150 \\ Email: beauty67@hansung.ac.kr
}

Received August 18, 2021

Revised September 1, 2021

Accepted September 17, 2021

Published September 30, 2021

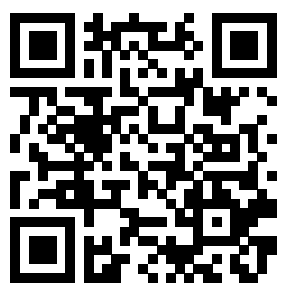

\begin{abstract}
Purpose: This study was conducted to investigate the possible use of Ponciri fructus bioconversion extracts as cosmetic ingredients. Method: Total polyphenol, total flavonoid content, and antioxidant effects of Poncirus trifoliata through the ability of diphenylpicrylhydrazyl (DPPH) radical scavenging were used for antioxidant activity determination. The extracts of Poncirus trifoliata were analyzed using an ultravioletvisible spectrophotometer Results: The total phenolic content was $62.5 \pm 4.19$ gallic acid equivalent (GAE) $\mathrm{mg} / \mathrm{g}$ in the case of alcohol extracts and $82.8 \pm 2.55$ $\mathrm{GAE} \mathrm{mg} / \mathrm{g}$ for other bioconversion extracts. Therefore, total flavonoids content was found to have increased by $32.4 \%$. The total flavonoid content of ethanol extracts was $30.1 \pm 3.15 \mathrm{mg} / \mathrm{g}$, whereas that of other bioconversion extracts was $39.5 \pm 35.1$ $\mathrm{mg} / \mathrm{g}$. Therefore, total flavonoids increased by $31.2 \%$. From DPPH radical results, the alcoholic extract increased from $65.5 \%$ to $75.5 \%$ after bioconversion. Thus, the bioconversion extracts increased by $10 \%$ compared with ethanol extracts. Conclusion: Poncirus trifoliata has excellent antioxidant effects, and it showed increased antioxidant activity after the bioconversion, thereby demonstrating its functional bioutility. Therefore, it can be used as an antioxidant material in the cosmetic and food industry.
\end{abstract}

Keywords: Poncrius trifoliate, Antioxidant, Bioconversion, Polyphenol, Flavonoid

\section{Introduction}

현대 사회는 생활 환경개선과 보건의료 기술의 발달로 인하여 사 람들의 수명이 연장되고 있으며, 더불어 소득 수준이 향상됨으로 사 람들은 '美'에 관심이 점점 더 높아지는 실정이다.

외모에 대한 아름다워지려는 욕구가 높아질수록 뷰티 관련 산업에 대한 관심은 더욱 증대되고 있으며, 남녀노소를 막론하고 뷰티산업 의 영역은 넓어지고 있다. 그리고 아름다움에 대한 욕구로 인하여 사 람들은 식생활과 운동을 하고 있지만 식생활 향상과 운동요법만으로 는 건강과 아름다움에 대한 욕구를 충족시키기에는 부족한 것이 현실 이다.

최근 연구 중 Bae \& Yoo (2015)의 연구에 의하면 대기 및 환경 공 해, 수질 오염, 과다한 농약 살포로 인한 농산물의 독성 때문에 인체 에 해로운 중금속 등이 축적 되고 있으며 생물학적 스트레스로 작용 하여 활성산소를 생성시켜서 피부노화, 질환, 훼손의 원인이 되기 때
문에 내적인 노력만으로는 건강과 미를 성취하기는 어려울 수 있다. 이러한 시대적, 환경적 요청에 부응하고자 이너뷰티 식품이나 기능 성을 가진 화장품에 대한 관심이 높아지면서 이런 제품 요구에 맞는 소재들을 발굴하기 위해 세포생물학적 실험, 동물실험, 인체에 대한 임상실험들이 화장품회사, 식품회사들을 중심으로 활발하게 이루어 지고 있다(Han et al., 2013). 이렇게 좋은 제품 개발과 더불어 각 소 재에 여러 가지 추출방법을 이용하여 생물학적 활성을 높이기 위한 발효연구들이 활발하게 진행되고 있는데 이런 많은 추출 방법 중 최 근에 특히 주목받고 있는 방법 중에 효소에 의한 발효를 이용하는 생 물전환방법이 유효한 성분의 함량을 높여주는 것으로 보고되고 있 다. 생물학적 활성이 뛰어난 생물전환은 특정한 유효성분의 함량을 더 증가시키고 피부에 빠르게 흡수될 수 있도록 도와주는데 목적이 있다(Bae \& Yoo, 2017).

인체 내에서 정상적인 기능을 수행하는 세포들은 대사과정에서 일상적으로 생산되는 활성 산소들을 미토콘드리아에서 카탈라아제 
(catalase), 슈퍼옥사이드 디스뮤테이즈(superoxide dismutase)및 과 산화효소(peroxidase)와 같은 항산화능 효소를 생산하여 제거함으로 균형을 유지한다(Bae \& Yoo, 2015).

그러나 스트레스(oxidative stress)에 산화적 영향을 받은 세포들 은 세포 내에 활성 산소들이 대량으로 증가하고 위와 같은 균형이 해 체된다(Lee \& Kim, 2021). 세포에 스트레스를 주는 산화적 원인들 은 일반적으로 흡연(cigarette smoke), 급격한 온도 변화(extreme temperature change) 및 자외선(UV)으로 알려져 왔다. 이러한 스트 레스에 의한 활성산소 종으로부터 건강을 유지하기 위하여 우리 몸은 다양한 효소 및 비 효소에 의한 활성산소 제거 시스템을 가동하고 있 지만 산화 스트레스가 지속적으로 발생하면 이에 대처하기 위한 외부 로부터의 충분한 항산화 물질의 추가적인 공급을 필요로 한다(Jeon et al., 2011). 이러한 관점에서 볼 때 베리류 등의 과일, 녹황색 채소 및 감귤류 등의 과일들은 생약재와 같은 항산화력을 갖는 파이토케 미칼(phytochemical)이 풍부한 천연 식품의 섭취하여 활성산소에 의 한 스트레스를 줄이는 것을 권장할 수 있겠다. 감귤류에 속하는 지실 (Ponciri Fructus)은 탱자나무(Poncirus trifoliata Rafinesque)의 열 매가 반쯤 자랐을 때 채취하여 썰어 말린 것을 말한다. 지실(Ponciri Fructus)에는 많은 비타민이 함유되어 있는데, 그중에서도 세포재생 에 효과적인 A, B, C가 피부에 노화를 방지 한다(NIFDSE, 2014).

한의학적으로 지실은 고신(苦辛), 미한(微寒)하고 비(脾), 위(胃), 대장경(大腸經)으로 들어가 파기소적(破氣消積), 화담소비(化痰消㿋) 의 효능이 있으며, 다음과 같은 약효가 있는 것으로 되어있다. 주로 식적정체(食積停滯), 변비복통(便秘腹痛), 사리불창(捨離不瘡), 이급 후중(理(利)急後症), 흥복창만(胸腹脹滿) 등에 사용된다. 즉, 소화불 량으로 인해 장에 정체되어 있는 것과 같은 음식물 적체 증상을 치료 하는 작용이 있다는 것이다.

일반적으로 담(淡)은 병리대사 산물로서 순환기나 소화기에 질병 을 일으킬 수 있는 원인이 된다. 지실은 담을 제거하는 효능이 있는 데 흥부 수종, 천식 및 심장질환 즉 심증경색이나 심증을 의미하는 것으로 현대의학에서는 해석이 가능하다. 최근에 새로운 생명공학 분야에서는 지실의 효능 및 효과로서 피부기능의 개선에 유효한 다양 한 파이토케미컬(phytochemicals)성분을 가지고 있어서(Lee et al., 2013) 한방 약재인 지실(枳實, Citrus aurantium)에서 얻어지는 천 연성분의 친수성 한방기능성 원료에 주목하고 있다(NIFDSE, 2014). 또한 근래에는 천연물에서 발효를 이용한 생리 활성 물질의 추출이 활발하게 진행되고 있다. 생물전환에 의한 천연물 추출은 미생물에 에너지원을 제외한 생리 활성 물질들이 대부분 그대로 남아 있고 미 생물에 의한 각종 가수분해효소들이 만들어지기 때문에 생체이용율 이 횔씬 높아지는 것으로 알려져 있다(Lee et al., 2013). 따라서 생물 전환을 통하여 지실에 포함되어 있는 기능성물질에 대한 생체이용율 을 높인다면 산화스트레스에 의한 피부노화 완화 및 개선작용을 하는 소재로의 가능성을 있을 것으로 발표되고 있으나 생물전환 지실 추출 물에 대한 자료가 미미한 것으로 조사되었다(Bae \& Yoo, 2017).
본 연구는 일반적인 에탄올 추출물과 동충하초 균사체 배양액을 이용한 생물전환 추출물을 가지고 적용을 하였을 때 어떠한 성분 변 화, 효능과 항산화 기능성에 어떠한 변화를 가져올 수 있는지에 대한 연구를 수행해보고, 생물전환추출물이 일반 추출물보다 항산화 활성 에 어떠한 영향을 미치는지를 알아보고자 하는데 목적이 있다.

\section{Method}

\section{1. 실험재료}

1) 시약 및 기기

시약으로는 Folin-Ciocalteau phenol reagent(Kanto Chemical co., Japan), gallic acid (Samchun, Korea) hesperidine (DaeJung, Korea) quercetin (Sigma-Aldrich, USA), Sodium hydroxide (Samchun), aluminium chloride (Samchun,), 1,1-diphenyl2-picryldrazyl radical (DPPH; Alfa Aesar, Japan), potassium persulfate (Samchun) 등에서 구입하여 사용하였으며, UV/VIS분광 광도계(Optizen POP; Mecasys Co., Korea)의 기기를 이용하여 측 정하였고. 지실은 건조된 상태로 경북의성 소재의 한약 생약협동조 합(한빛약초)에서 구입하여 사용하였다.

\section{2) 균주의 준비}

지실을 발효하기 위한 동충하초 균주는 자작리톨 바이오 연구소에 서 보관하고 있는 코디셉스 밀리타리스(Cordyceps militaris) 균사체 를 $\mathrm{PDA}$ (Difco)배지에 접종하여 21 일 동안 $24^{\circ} \mathrm{C}$ 에 1차 종 배양하였 다. 이후, 1 차 종 배양된 배양여액을 $500 \mathrm{~mL}$ 삼각플라스크에 $\mathrm{YM}$ 배 지(Glucose, Malt extract, Pepton, Yeast extract)를 넣고 접종하여 진탕배양기에서 $24^{\circ} \mathrm{C}$ 의 온도와 $100 \mathrm{rpm}$ 의 교반조건으로 7 일 동안 배양하였다. 2 차 배양 이 끝난 후 동충하초 균사체를 수거하여 블렌 더(Waring blender, Cole Parmer Co., USA)로 균질화 시킨 후 사용 하였다.

\section{3) 지실 추출물의 준비}

지실의 성상은 부분적인 반공모양으로 지름이 1-4 cm이고, 바깥 면은 갈색에서 녹색을 띠며 오목하고 거친 작은 점이 많다. 내면은 깨끗하지 않은 회색이고 가운데로부터 방사상으로 8-16개의 작은 쪽으로 되어 있고, 이 작은 쪽들은 건조되면 동그랗게 쪼그라들고 가 끔은 덜 익은 황백색의 씨가 들어 있다. 냄새가 독특하고 시고 쓴 맛 이 있다.

지실은 엄선된 지실 건재를 피부에 대한 자극이 적으면서 피부보 습 및 자체 방부기능을 가지 고 있는 polyhydric Alcohol을 추출 용제 로 이용하여 일정시간 동안 저온/감압 추출 후 여과 정제들의 과정의 공법으로 추출하는 (주)하우연 업체에서 액상 상태로 구입하여 사용하 였다. 
4) 지실의 생물전환 추출물의 준비

지실의 생물전환은 2)에서 준비한 동충하초 균사체 배양여액에 건 조한 상태로 구입한 지실을 동충하초 균사체 배양여액 $80 \mathrm{~L}$ 에 지실 건조물 $8 \mathrm{~kg}$ 을 넣어서 발효 숙성 장치에 동시에 넣고 $60^{\circ} \mathrm{C}$ 조건에서 약 21 일 동안 숙성발효를 진행하였다. 21 일이 경과한 후 추출액을 회 수하고 지실 고형물은 폐기하였다. 회수된 동충하초 균사체 배양여 액 생물전환 추출물은 실험을 위하여 $4^{\circ} \mathrm{C}$ 냉장상태에서 보관하였고 실험 전에 여과하여 사용하였다.

\section{2. 항산화 효능 실험}

항산화(antioxidation)시험이란 활성산소를 제거하는 효과를 갖는 물질의 양을 측정하는 시험이다(Han et al., 2003) 활성산소를 발생 시켜 세포의 노화과정과 질병을 발생시키는 산화를 예방하는 방법을 설명하는 개념이 항산화이다. 즉, 세포의 노화는 세포가 산화된 것 을 의미하기 때문이다. 호흡기를 통하여 체내로 들어오는 산소는 대 사작용에 필요한 에너지를 만들기도 하지만, 이 대사과정에서 여러 원인으로 인하여 인체에 해로운 활성산소(free radical)가 생성되기 도 한다. 체내의 정상 세포를 공격하여 각종 질병의 발생, 노화진행 에 활성산소가 작용한다(Park et al., 2007). 따라서 이러한 세포의 산화(노화)를 막으려면 활성산소를 제거해야 한다. 이러한 일련의 세 포의 산화억제 과정을 항산화라고 한다. 천연물들 중에는 항산화 효 과를 나타내는 식물들이 있는데, 꿀, 아로니아, 아사이베리, 불루베 리, 노니등이 있고, 식물 들에서 추출한 항산화 물질로는 카로티노 이드(carotinoid)류로 베타카로틴, 라이코펜, 루테인등이 있고, 플라 보노이드(flavonoid)류 안토시아닌, 카테킨, 레스베라트롤 등이 있으 며, 이소플라빈(isoflavin)류, 비타민, 미네랄 등이 있다. 주요 항산화 효능을 보기위한 시험으로는 총 페놀함량(total phenolic contents) 시험, 총플라보노이드함량(total flavonoids contents)시험, 총 안토 시아닌함량(total antocyanin contents)시험, DPPH 소거능 (DHHP radical)시험, ABTS 시험(ABTS assay), FRAP 시험(FRAP assay), $\mathrm{ORAP}$ 시험(ORAP assay) 같은 방법들이 있다.

항산화 효능측정시험의 이론적인 근거는 항산화 능력을 직접 확 인하는 구도가 아니고 총 페놀함량, 총 플라보노이드 함량을 측정 해서 플라보노이드 함량이 많으면 많을수록 항산화 효과(Hwang et al., 2015)가 높게 나타날 것이라고 유추하는 가설에 두고 있다(Kang et al., 2021). 그러므로 본 연구에서는 총 페놀함량측정시험(total phenilic contents), 총 플라보노이드 함량 시험(total flavonoids contents), DPPH radical 소거능 등의 시험을 수행하고 시험결과를 상호 비교 평가하여 연구의 신뢰도를 높이고자 하였다.

\section{1) 총폴리페놀 함량(total phenolic contents) 시험}

총 폴리페놀 화학물 함량은 gallic acid를 표준물질로하여 FolinCiocalteu (Singleton et al., 1965)의 방법에 따라 측정하였다. 각 시 료를 증류수에 $50 \mathrm{mg} / \mathrm{mL}$ 로 희석한 후 $0.2 \mathrm{~mL}$ 에 Folin-Ciocalteu's phenol을 $0.2 \mathrm{~mL}$ 를 더한 후 $25^{\circ} \mathrm{C}$ 에서 $3 \mathrm{~min}$ 간 반응시키고, $10 \%$ $\mathrm{Na}_{2} \mathrm{CO}_{3} 3 \mathrm{~mL}$ 를 첨가하여 $25^{\circ} \mathrm{C}$ 에서 $1 \mathrm{~h}$ 간 놓아둔다. 이 시료를 흡 광도를 UV/Vis-spectrophotometer (Optizen POP; Mecasys Co, Korea)로 $765 \mathrm{~nm}$ 로 맞추고 측정하였다. Gallic acid (Sigma)를 20 $\mathrm{mg} / \mathrm{L}$ 에서 $20 \mathrm{mg} / \mathrm{L}$ 농도를 더해가며 연속적인 농도의 표준용액을 만들고 이 시료 $1 \mathrm{~mL}$ 에 extrapure D.W $9 \mathrm{~mL}$ 를 섞어서 사용하였다. 표준검량선을 작성하고 시료 중 농도를 gallic acid equivalent (GAE $\mathrm{mg} / \mathrm{g}$ )로 환산하여 총 폴리페놀을 측정하였다.

2) 총플라보노이드 함량 (Total flavonoids contents) 시험

총플라보노이드함량 정량법에는 여러 가지가 있지만 본 실험에서 는 염화 알루미늄(aluminium chloride )을 사용한 발색법을 사용하 였다. 염화 알루미늄은 플라보노이드와 결합하여 산(acid)에 불안정 한 복합체(complex)를 형성하게 되는 데 이 복합체를 다른 용액과 반 응시켜서 발색을 시키고 그 색농도를 통해 플라보노이드의 양을 측정 하였다. 시료 $1000 \mu \mathrm{L}$ 에 $5 \% \mathrm{NaNO}_{2}$ (w/v) $60 \mu \mathrm{L}$ 와 $10 \% \mathrm{AlCl}_{3}(\mathrm{w} / \mathrm{v}$ ) $60 \mu \mathrm{L}$ 를 첨가한 뒤 $5 \mathrm{~min}$ 간 반응시킨다. $1 \mathrm{M} \mathrm{NaOH}$ 용액 $400 \mu \mathrm{L}$ 와 $\mathrm{D} . \mathrm{W} 480 \mu \mathrm{L}$ 를 첨가하고 $6 \mathrm{~min}$ 간 반응시키고, 반응이 끝난 뒤 510 $\mathrm{nm}$ 에서 흡광도를 측정하였고, 표준물질로는 헤스페리딘을 사용하였 다. 표준검량곡선은 총페놀 측정 시와 동일하게 시행하였다.

\section{3) $\mathrm{DPPH}$ 라디칼 소거능 (DPPH radical assay)}

$\mathrm{DPPH}$ 분석은 $\mathrm{DPPH}$ (Sigma)을 대상으로 시료가 가지고 있는 Radical 소거(radical scavenging) 효과를 측정하는 방법이며, Blois (1958)의 방법을 적용하여 측정하였다(Jung et al., 2019). Methanol 에 희석시킨 $0.2 \mathrm{mM} \mathrm{DPPH}$ 용액 $1 \mathrm{~mL}$ 에 시료 $1 \mathrm{~mL}$ 를 더한 후에 $10 \mathrm{~min}$ 간 진탕기(vortex mixer)로 혼합하고 실온에서 $30 \mathrm{~min}$ 간 놓 아둔 후 $517 \mathrm{~nm}$ 에서 흡광도를 측정하였다. 다음의 공식을 이용하여 각 시료농도에 따른 소거활성 표준곡선을 그린 뒤 $\mathrm{DPPH}$ free radical scavenging activity의 $50 \%\left(\mathrm{DPPH} \mathrm{IC}_{50}\right)$ 해당하는 수치를 구하였다.

$\mathrm{DPPH}$ free radical scavenging activity $(\%)=[($ 추출물 첨가 무(無) 시료 흡광도-추출물 첨가구 흡광도)/(추출물 첨가 무(無) 시료 흡광 도) $\times 100$

\section{4) 통계처리}

본 연구의 실험결과는 3 회이상 반복적으로 측정하여 평균값을 구 하여 나타내었으며 통계학적 유의성은 Student's $t$-test로 분석하였 고 $p$ value가 0.05 미만인 경우를 유의한 통계로 판정하였다.

\section{Results}

\section{1. 총페놀함량 및 총플라보노이드 함량시험}

지실 에탄올 추출물 및 생물전환 추출물을 분석하여 비교하여 보 
았다. 지실 에탄올 추출물에는 $62.5 \pm 4.19 \mathrm{GAE} \mathrm{mg/g}$ 의 총 폴리페 놀이, 생물전환 추출액에는 $82.8 \pm 2.55 \mathrm{GAE} \mathrm{mg/g으로} \mathrm{약} 32.4 \%$ 증가된 것으로 나타났다(Table 1).

지실에 들어있는 것으로 알려진 naringine, luteolin, hesperidine 등과 같은 총 플라보노이드 화합물 중에서 본 연구에서는 hesperidine을 지표물질로 하여 측정을 하였다. 지실 에탄올 추출물 에는 $30.1 \pm 3.15 \mathrm{mg} / \mathrm{g}$ 의 총플라보노이드와 생물전환 추출물에는 $39.5 \pm 3.5 .1 \mathrm{mg} / \mathrm{g}$ 으로 나타나서 약 $31.2 \%$ 증가되는 것으로 나타났 다.

\section{DPPH 소거능 분석}

$\mathrm{DPPH}$ 측정방법은 프리라디칼인 활성산소가 생체고분자 지질단 백질등과 결합하여 피부노화 및 각종 질병을 유발하는 인자로 밝혀 진 이후로 항산화 물질들의 라디칼 소거능력을 보는 지표로 이용되고 있다(Kim et al., 2012). 본 실험결과로 양성대조군인 quercetin에서 는 $1 \%$ 의 농도에서 $92.7 \%$ 의 높은 라디칼 소거활성이 확인되었다. 지 실 에탄올 추출물과 지실 생물전환 추출물의 $\mathrm{DPPH}$ 소거능 결과는 Table 2과 같다. DPPH 소거능에서 지실 에탄올 추출물에서는 $65.5 \%$ 인 반면에 생물전환 추출물에서는 $75.5 \%$ 로 측정치가 나타나서 생물 전환 추출을 했을 때 약 $10 \%$ 정도 증가되는 것을 보여준다(Table 2).

$\mathrm{DPPH}$ 의 측정방법은 활성산소 라디칼이 지질단백질 등과 같은 생 체 고분자들과 결합하여 각종 질병 및 피부노화를 유발하는 것으로 밝혀지므로 항산화 물질의 활성산소 라디칼의 소거능력을 측정하는 데 이용되고 있다.

\section{Discussion}

본 연구에서는 오랫동안 민간요법에 이용되어왔던 지실의 항염증, 항산화, 피부개선, 노화 등의 생리적 기능 개선능력에 주안점을 두고 실험실에서 항산화력 측정을 통하여 과학적으로 규명해 보고자 하였
고, 또한 생물전환 추출방법과 에탄올 추출방법(Kim et al., 2020)을 가지고 동일한 실험을 하여 위와 같은 생리적 기능개선의 효능효과에 대한 차이를 찾아보고자 하였다.

지실의 항산화능을 보기 위한 실험에서 지실 에탄올 추출물과 생 물전환 지실 추출물의 총 페놀의 함량를 측정하기 위해 표준물질로 gallic acid를 사용하였고 총플라보노이드의 함량을 측정하기 위하여 표준물질로는 hesperidine을 사용하였다. 그 결과 Table 2에서와 같 이 총 페놀의 함량이 지실 에탄올 추출물에는 $62.5 \pm 4.19 \mathrm{GAE} \mathrm{mg/}$ $\mathrm{g}$, 생물전환 지실 추출물에는 $82.8 \pm 2.55 \mathrm{GAE} \mathrm{mg} / \mathrm{g}$ 이 측정되어 지 실생물전환시에 약 $32 \%$ 증가되는 것으로 나타났고, 총 플라보노이 드 함량은 지실 에탄올 추출물이 $30.1 \pm 3.15 \mathrm{mg} / \mathrm{g}$ 로 생물전환 지실 추출물에는 $39.5 \pm 3.5 \mathrm{mg} / \mathrm{g}$ 로 나타나서 역시 지실을 생물전환 추 출 시 약 $30 \%$ 정도 증가하는 것으로 나타났다. $\mathrm{DPPH}$ 소거능은 지실 에탄올 추출물에서 $65.5 \%$, 지실 생물전환 추출물에서 $75.5 \%$ 로 지 실의 생물전환 추출 시 약 $10 \%$ 정도 증가하는 것으로 나타났다. 이러 한 결과는 배영민(Bae \& Yoo, 2015)등이 보고한 발효김치로부터 분 리한 프로바이오틱스 균주에 의한 지실추출물 발효와 항산화능 분석 논문에서 지실 열수추출물을 사용한 경우에 총페놀 함량이 $71.2 \pm$ $4.58 \mathrm{mg} / \mathrm{g}$ 로 나타났고, 발효추출물에는 $89.2 \pm 13.47 \mathrm{mg} / \mathrm{g}$ 로 나타 나서 약 $25.5 \%$ 증가한 것으로 보고되고 있고, 총플라보노이드는 지 실 열수 추출물에서 $25.1 \pm 4.12 \mathrm{mg} / \mathrm{g}$ 의 결과가, 지실 발효추출물에 는 $31.0 \pm 4.06 \mathrm{mg} / \mathrm{g}$ 으로 나타나서 $23.5 \%$ 증가한 것으로 보고되었 다. $\mathrm{DPPH}$ 소거능은 지실 열수추출물에서 $70.9 \%$ 로, 지실 발효추출물 에서는 $86.2 \%$ 로 측정되어 지실 발효추출 시 $15.5 \%$ 정도 증가된 것으 로 보고되었다. 또한 Heo et al. (2007)이 보고한 동충하초의 균사 및 배양액의 항산화, 항암, 면역활성에 연구에서 균사체보다 균사배양 의 생물전환에 의한 폴리페놀과 플라보노이드 함량이 증가한다는 결 과들 과도 일치하는 것으로 보여 진다(Kim et al., 2021). 그리고 선 행연구(Bae \& Yoo, 2015)에서 나타났던 것처럼 지실은 생물전환을 통해 우수한 항산화 활성을 가지는 소재(Yoon et al., 1992; Hwang et al., 1997)로 나타났고, 생물전환(Bae \& Yoo,, 2017)을 하였을 때

Table 1. Total phenolic compounds and total flavonoid compounds of the ethanol extracts and bioconversion extracts of Poncirus trifoliate

\begin{tabular}{lcc}
\hline & Total flavonoid & Total phenolic \\
Ethanol extract & $62.5 \pm 4.19$ & $30.1 \pm 3.15$ \\
Bioconversion extract & $82.8 \pm 2.55$ & $39.5 \pm 3.5$ \\
\hline
\end{tabular}

Total flavonoid contents expressed as hesperidine equivalents $\mathrm{mg} / \mathrm{g}$ dried hotwater extracts. Values are means $\pm S D(n=5)$. Total phenolic contents were expressed as gallic acid equivalents (GAE) $\mathrm{mg} / \mathrm{g}$ dried hot water extracts. Values are means $\pm S D(n=5)$.

Table 2. DPPH scavenging capacity of ethanol and bioconversion extracts of Poncirus trifoliate

\begin{tabular}{lc}
\hline & DPPH radical \\
Poncirus trifoliate ethanol extracts & 65.5 \\
Poncirus trifoliate bioconversion extracts & 75.5 \\
\hline
\end{tabular}

The DPPH scavenging was measured at $30 \mathrm{~min}$ of antioxidant-radical reaction. Values are means $\pm S D(n=5)$. 
는 유효한 성분인 총플라보노이드, 총페놀의 함량을 높여주는 것으 로 보고되어 본 연구와 같은 결과를 보여주고 있는 것으로 나타났다. 다만 선행연구(Bae \& Yoo, 2015)에서는 프로바이오틱스를 이용하여 생물전환을 하였고, 본 연구에서는 동충하초 균사체 배양여액에 의 한 생물전환을 시도하였는데도 유사한 실험결과를 얻었다.

\section{Conclusion}

본 연구는 최초로 동충하초 균사체 배양여액에 의한 생물전환 추 출을 하여 유효성분의 함량을 더 증가시키고 생물학적 활성을 높여서 피부에 빠르게 흡수될 수 있도록 도와주는 소재로 이용해 보려는 시 도를 하였다. 선행연구(Bae \& Yoo, 2015)에서도 나타났던 것처럼 본 연구에서도 지실은 생물전환을 통해 우수한 항산화 활성을 가지는 소 재(Yoon et al., 1992; Hwang et al., 1997)로 나타났다. 지실에 대 하여 동충하초 배양여액을 가지고 생물전환(Bae \& Yoo, 2017)을 하 였을 때는 유효한 성분인 총플라보노이드, 총페놀의 함량을 높여주 는 것으로 보고되었다. 결론적으로 향후 지실이라는 천연물 소재를 동충하초 균사체 배양여액을 통한 생물전환을 하여 추출의 효율성, 항산화 능력을 증가시키는 연구를 계속하고 보완한다면 지실 추출물 의 생체 이용률을 높이고 기능성 화장품, 식품의 소재로서 활용가치 가 높을 것으로 사료된다.

\section{Author's contribution}

G.B.K contributed equally to this work. G.B.K designed all experimental investigation and made a totally experiment, wrote the manuscript in assist of O.H.K. O.H.K controlled this project and contributed to all the parts of analysis and experimental interpretations.

\section{Author details}

Gyubin Kong (Graduate student), Major of Beauty Design Magagement, Department of Media Design, Hansung University, 116 Samseongyo-ro 16-gil, Seongbukgu, Seoul 02876, Korea; Ohhyeok Kwon (Professor), Department of Beauty Design Management, Hansung University, 116 Samseongyo-ro 16-gil, Seongbuk-gu, Seoul 02876, Korea.

\section{References}

Bae YM, Yoo SK. Probiotic microbial fermentation of Poncris trifoliata extract by probiotic strain isolated from fermented
Gimchi and antioxidant activity. Journal of Korean Applied Sciences and Technology, 32: 568-577, 2015.

Bae HK, You SH. Biological activity study on anti-oxidant, whitening, and anti-inflammatory effects of Astragalus membraneous ethanol extracts and bioconversion extracts. Asian Journal of Beauty and Cosmetology, 15: 489-499, 2017.

Blois MS. Antioxidant determinations by use of a stable free radical. Nature, 181:1199-1200, 1958.

Han YS, Jung ES. A study of correlation between antioxidant activity and whitening effect of plant extract. Asian Journal of Beauty and Cosmetology, 1: 11-22, 2003.

Heo JH, Nam SH, Kang SW, Hong IP, Lee KK, Park JY, Kim KH, Han SY, Lee SH. Comparison of antioxidant, anticancer and immunomodulating activities of extracts from DongChongXioCao. Korean Journal of Food Preservation, 14: 681-687, 2007.

Hwang GS. Analytical study on the flavonoid of Poncirus trifoliata. Journal of Society of Preventive Korean Medicine, 1: 55-58, 1997.

Hwang JS, Lee BH, An XX, Jeong HR, Kim YE, Lee li, Lee HJ, Kim DO. Total phenolics, total flavonoids, and antioxidant capacity in the leaves, bulbs, and roots of Allium hookeri. Korean Journal of Food Science and Technology. 47: 262266, 2015.

Jeon JM, Choi SK, Kim YJ, Jang SJ, Cheon JW, Lee HS. Antioxidant and antiaging effect of ginseng berry extract fermented by lactic acid bacteria. Journal of the Society of Cosmetic Scientists of Korea, 37: 75-81, 2011.

Jung YH, Han JS, Kim AJ. Quality evaluation and antioxidant activities of inner beauty tea prepared from roasted Lotus root and Burdock. Asian Journal of Beauty cosmetology, 17: 235-245, 2019.

Kang BH, Ryu MJ. Physiological activities of the neem and the comfrey extracts as cosmetic ingredients. Asian Journal of Beauty and Cosmetology, 19: 223-234, 2021.

NIFDSE. Poncirus fructus Immaturus. Ministry of Food and Drug Safety, Cheongju-si, pp2-7, 2014.

Kim HS, Ko KS. Antioxidant and anti-inflammatory effects of ginseng berry ethanol extracts as a cosmetic ingredient. Asian Journal of Beauty and Cosmetology, 18: 389-397, 2020.

Kim JP, Yang YS, Kim JH, Lee HH, Kim ES, Moon YW, Kim JY, Chung JK. Chemical properties and DPPH radical 
savenging ability of SwordBean(Canavalia gladiate) extract. Korean Journal of Food Scientific Technology, 44: 441-446, 2012.

Kim SY, Shin SY, Kim JH, Lee HJ, Kim KM. Antioxidant and moisturizing effects of fermented Hordeum vulgare $\mathrm{L}$. effect and heat-killed probiotics by Lactobacillus lactic acid bacteria isolated from kimchi. Korean Journal of Microbiology, 57: 35-38, 2021.

Lee GW, Park SM, Yoo YC, Cho YH. Effect of Ponciri Fructus extracts fermented with Ganoderma lucudum on the collagen synthesis and expression of matrix metalloproteinase-1. Korean Society for Biotechnology and Bioengineering Journal, 28: 106-114. 2013.
Lee SM, Kim CD. Antioxidant effect of leaf, stem, and root extracts of Zingiber officinale as cosmetic materials. Asian Journal of Beauty and Cosmetology, 19: 23-33, 2021.

Park YK, Choi SW, Kim SH, Han J, Chung HG. Changes in antioxidant activity, total phenolics and vitamin $\mathrm{C}$ content during fruit ripening in Rubus occidentalis. Korea Journal Plant Resources, 20: 461-465, 2007.

Singleton VL, Rossi JA. Colorimetry of total phenolics with phosphomolybdic-phosphotungstic acid reagents. American Journal of Enol Viticult, 16: 144-158, 1965.

Yoon HK, Kim DH. Biological active components of fruits of Poncirus trifoliata. Yakhak Hoeji, 36: 548-555, 1992. 


\section{국문초록}

\section{지실 생물전환 추출물의 항산화 효과}

공규빈 ${ }^{1}$, 권오혁 ${ }^{2 *}$

1한성대학교 미디어디자인학과 뷰티디자인매니지먼트전공, 서울, 한국

${ }^{2}$ 한성대학교 디자인대학 뷰티디자인매니저먼트학과, 서울, 한국

목적: 본 연구는 지실의 기능성 화장품 및 식품소재로서의 활용 가능성을 알아보기 위하여 에탄올 추출물과 동충하초 균사체 배양 여액으로 생물전환한 지실추출물을 가지고 실험을 진행하여 보았다. 방법: 지실 에탄올 추출물과 동충하초 균사체 배양여액을 가지 고 총폴리페놀, 총플라보노이드 함량측정과 2,2-diphenyi-1-picrylhydrazyl (DPPH)소거능 활성을 통한 지실 추출물의 항산화 효 과 등을 알아보고 에탄올 추출물과 생물전환 추출물의 결과 비교를 통하여 생물전환방법에 의한 유효성분의 함량변화, 항산화능 차 이를 비교하여 보았다. 결과: 이 실험을 수행한 결과 에탄올 추출물의 경우에는 총 페놀함량이 $62.5 \pm 4.19 \mathrm{GAE} \mathrm{mg/g} \mathrm{있는} \mathrm{것으로}$ 나타났고 생물전환 추출물은 $82.8 \pm 2.55 \mathrm{GAE} \mathrm{mg/g으로} \mathrm{약} 32.4 \%$ 증가되었고, 총 플라보노이드는 에탄올 추출물의 함량이 30.1 $\pm 3.15 \mathrm{mg} / \mathrm{g}$, 생물전환 추출물은 $39.5 \pm 35.1 \mathrm{mg} / \mathrm{g}$ 으로 약 $31.2 \%$ 증가된 것으로 나타났다. DPPH 소거능은 에탄올 추출물의 경우 에는 $65.5 \%$, 생물전환 추출물은 $75.5 \%$ 인 것으로 나타났다. 결론: 지실 추출물은 항산화 효과가 우수하였으며 생물전환을 하였을 때 에탄올 추출에 의한 것보다 약간 증가된 것으로 나타났으며, 생물전환을 통하여 지실에 들어있는 기능성 물질에 대한 추출률과 생체 이용률을 높인다면 여러 가지 산화스트레스 요인으로 발생할 수 있는 활성산소에 의한 피부 내. 외적인 문제들을 개선할 수 있 는 화장품, 식품 소재로서의 가능성이 높을 것으로 사료된다.

핵심어: 지실, 생물전환, 폴리페놀, 항산화능, 플라보노이드

\section{참고문헌}

강복희, 유민정. 님과 컴프리 추출물의 화장품소재로써 생리활성 연구. 아시안뷰티화장품학술지, 19: 223-234, 2021. 김종필, 양용식, 김진희, 이향희, 김은선, 문용운, 김진영, 정재근. 작두콩 추출물의 화학적 특성 및 $\mathrm{DPPH}$ 라디컬 소거능. 한국식품과학회지, 44: 441-446, 2012.

김현숙, 고경숙. 인삼열매 에탄올 추출물의 화장품 소재로서 항산화, 항염 효과. 아시안뷰티화장품학술지, 18: 389-397, 2020.

박영기, 최선하, 김세현, 한진규, 정헌관. 블랙 라스베리의 과실 성숙에 따른 항산화 활성, 총페놀 함량 및 비타민 C 함량 변화. 한국자원식물학회지, 20: 461-465, 2007.

배영민, 유선균. 발효 김치로부터 분리한 프로바이오틱 균주에 의한 지실추출물 발효와 항산화능 분석. 한국유화학회지, 32: 568-577, 2015.

배혜경, 유선희. 황기 에탄올 추출물 및 생물전환 추출물의 항산화, 미백, 항염증에 대한 생리활성. 아시안뷰티화장품학술 지, 15: 489-499, 2017.

식품의약품안전평가원 생약연구과. 지실(枳實). 식품의약품안전처, 청주시, $\mathrm{pp} 2-7,2014$. 윤황금, 김동현, 김남재, 홍남두. 지실의 생리활성 성분. 약학회지, 36: 548-555, 1992.

이계원, 박성민, 유영춘, 조영호. 콜라겐 합성과 MMP-1 발현에 대한 생물전환 지실 추출물의 효과. KSBB Journal, 28: 106-114, 2013

이상무, 김춘득. 생강의 잎, 줄기, 뿌리 추출물의 항산화효과. 아시안뷰티화장품학술지, 19: 23-33. 2019.

전지민, 최성규, 김윤정, 장수진, 천종우, 이현상. 유산균발효에 의한 인삼열매 추물물의 항산화 및 항노화 효과. 대한화장 품학회지, 37: 75-81, 2011. 
정연희, 한정순, 김애정. 로스팅한 연근과 우엉을 이용한 이너뷰티 차의 항산화 활성과 품질평가. 아시안뷰티화장품학술 지, 17: 235-245, 2019.

한영숙, 정은선. 천연식물추출물의 항산화력과 미백작용의 상관관계연구. 아시안뷰티화장품학술지, 1: 11-22. 2003. 황귀서. 지실에 함유된 Flavonoid 성분의 분석. 대한예방한의학회지, 1: 55-58, 1997.

황정승, 이봉한, 안향설, 정하람, 김영은, 이인일, 이형재, 김대옥. 삼채의 잎, 인경, 뿌리의 총페놀 함량, 총플라보노이드 함량 및 항산화능. 한국식품과학회지, 47: 262-266, 2015. 


\section{中文摘要}

\section{枳实生物转化提取物的抗氧化作用}

孔閨涁 ${ }^{1}$, 權五赫 ${ }^{*}$

1汉城大学媒体设计科美容设计管理系, 首尔, 韩国

汉城大学美容设计管理科, 首尔, 韩国

目的：探讨枳实生物转化提取物作为化妆品成分的可能性。方法：测定总多酚、总黄酮含量和二苯基苦味酸 (DPPH) 自由基清除能力来确定枳实的抗氧化活性。采用紫外-可见分光光度计对枳实提取物进行了分析。结 果: 乙醇提取物的总酚含量为 $62.5 \pm 4.19 \mathrm{GAE} \mathrm{mg} / \mathrm{g}$, 生物转化提取物的总酚含量为 $82.8 \pm 2.55 \mathrm{GAE} \mathrm{mg} / \mathrm{g}$ 。因 此，发现总黄酮含量增加了 $32.4 \%$ 。乙醇提取物的总黄酮含量为 $30.1 \pm 3.15 \mathrm{mg} / \mathrm{g}$, 而生物转化提取物的总黄 酮含量为 $39.5 \pm 35.1 \mathrm{mg} / \mathrm{g}$ 。因此, 总黄酮增加了 $31.2 \%$ 。从DPPH自由基结果来看, 生物转化后乙醇提取物从 $65.5 \%$ 增加到 $75.5 \%$ 。因此，与乙醇提取物相比，生物转化提取物增加了 $10 \%$ 。结论: 枳实具有良好的抗氧化作 用, 经生物转化后抗氧化活性增强, 显示了其功能性生物效用。因此, 它可以用作化妆品和食品工业中的抗氧 化原料。

关键词: 枳实，抗氧化剂，生物转化，多酚，类黄酮 
